\title{
Translating History or Romance? Historical Romantic Fiction and Its Translation in a Globalised Market
}

\author{
Diana Bianchi ${ }^{1}$, Adele D'Arcangelo ${ }^{2, *}$ \\ ${ }^{1}$ Department of Political Sciences, University of Perugia, Italy \\ ${ }^{2}$ DIT Department, University of Bologna, Forlì Campus, Italy
}

Copyright ( $(2015$ by authors, all rights reserved. Authors agree that this article remains permanently open access under the terms of the Creative Commons Attribution License 4.0 International License

\begin{abstract}
Popular romance literature has long been neglected and underestimated in the global literary context and little research on the translation of this genre has been carried out so far. Even taking into account its "popular connotation", romantic fiction seems to occupy the lower shelf in the literary polysystem compared with other popular genres. The discrepancy between the importance of this genre in the publishing industry and the scarce attention given to it by traditional scholars means that little is known about the textual practices and processes that accompany its production and circulation, including translation. In this paper, we deal with the issue of translating romantic fiction, focusing on the specific translation of historical romances, one of its most popular subgenres. In particular, through the analysis of a specific case study, the novel Outlander by American author Diana Gabaldon, we suggest that the double filiation of historical romances, i.e. their connection to both popular and canonical traditions, may have consequences at the textual level as when such books are translated, their ambiguous generic labelling tends to be resolved, favouring either the romantic or the historical component, thus resulting in a stronger generic identity. ${ }^{1}$
\end{abstract}

Keywords Literary Translation, Romance, History, Popular Fiction

\section{Introduction}

The production and consumption of romantic fiction is a global phenomenon, a key element of both international and national publishing industries. According to recent sales figures, romance ${ }^{2}$ fiction comprises more than half sales in

\footnotetext{
${ }^{1}$ A first version of this article was presented by both authors at the 2014 Translata Conference, held at the University of Innsbruck (30 October-1 November). Although both authors have contributed to the overall draft and have written abstract and conclusions together, Adele D'Arcangelo is primarily responsible for Section 1 and 2 of the article and Diana Bianchi for section 3.

${ }^{2}$ Terms such as "romantic fiction" and "romance" may be ambiguous as
}

popular paperback fiction and generates almost 1.5 billion dollars per year in sales in North America alone. In Italy, Harlequin Mondadori - the big editorial joint venture leader for female romance fiction in the country for more than 30 years - publishes more than 600 titles each year, amounting to a total of 260 million books sold in the last 20 years, and a total invoice of 20 million euros. For the specific purpose of this article it is also worth remembering that $99 \%$ of Harlequin books are translated (especially from US authors) and only $1 \%$ are written by Italian authors. ${ }^{3}$

However, in spite of such success, romantic popular literature is still perceived as an inferior type of cultural production and has received little attention by critics, with the exception of a few individuals and specific study groups ${ }^{4}$. As Barbara Fuchs states: "[..] despite its popularity, even within the larger category of mass genre fiction, the term romance marks the most criticized and also less recognized kind, the one associated with young or infantile female readers, and particularly deplored." [1: p. 129] In the area of translation, contributions are even scarcer as, before and after the emergence of Translation Studies as a distinct discipline in the 1980 s, translation scholars have generally privileged the study of literary texts that are part of the canon or 'official' literature. The few studies on the translation of popular romance either focus on the specific subgenre of category romances (see for example George Paizis [3]) or concern themselves with pre-industrial texts whose form and function was different from the texts under examination in this article, as, for example, the translation of popular medieval romances discussed in Weiss et al [4].

The result of this neglect is that little is known of the

they have been used to refer to different types of narratives in different times (see Fuchs [1: p. 1-4]). In this article we use these terms in relation to the mass-market texts published since the twentieth century and centered on a love story, as defined in Section 2.

3 Data about sales come respectively from the $R W A$ at: https://www.rwa.org/p/cm/ld/fid=580 and from Alessandra Bazardi, Editorial Manager at Harlequin Mondadori (see Carmignani [2])

4 See for example the International Association for the Study of Popular Romance (IASPR at: http://iaspr.org/ ) and the academics gathered round the recently formed group Teach Me Tonight. Musings on Romance Fiction from an academic perspective at: http://teachmetonight.blogspot.it/ 
textual practices that characterise the production of popular romantic fiction, particularly when it is translated for a new cultural context and readership.

In this paper we address this issue focusing on the translation of historical romances, a genre that, in the last decades, has become particularly popular in terms of sales and international appeal. From a translational point of view these novels pose interesting problems as, while the romantic aspects may be seen as transnational (at least in western culture), history is local and national and perhaps less appealing for target readers. Since, as Shibamoto Smith [5] indicates, the audience's expectations constitute an important criterion when translating romantic fiction, the question we ask is how the different components of historical romances are dealt with in translation, i.e. to what extent is the historical part translated? What is adapted and/or cut out? Are any particular historical periods seen as less 'appealing' in the target culture? Who is not translated?

We will examine these issues through a specific case study, the analysis of the Italian translation of the novel Outlander by American author Diana Gabaldon whose generic identity has been questioned and negotiated, due to its combination of history, fantasy and romance. Before presenting the results of our analysis we will provide a brief overview of the main generic features of romantic fiction and, in particular, of historical romances, as the way in which these genres are defined and understood by the operators in the field is important to get insights into the practices that characterize their consumption and circulation.

\section{Defining 'Popular Romances' and 'Historical Romances'}

Although definitions of "popular romances" have been provided within the academic environment ${ }^{5}$, it is of particular interest to see the definition given by the Association of the Romance Writers of America (RWA), as, for the purposes of this article, it is essential to see which elements are to be considered fundamental in order to gain the interest of the market, hence to generate trends not only in terms of sales but also in relation to the readers' favourite elements: in short, it is important to see what makes these books popular as a market product.

The RWA states that to be labelled as romance a fiction needs to present the following aspects:

- A central Love Story: in a romance the main plot concerns two people falling in love and struggling to make the relationship work. The conflict in the book centres on the love story, the climax in the book resolves the love story. A writer is welcome to as many subplots as she ${ }^{6}$ likes as long as the relationship conflict is the main story

5 See for example Pamela Regis [6]

6 Romance novels are preeminently written by women.
- An emotionally satisfying and optimistic ending: romance novels end in a way that makes the reader feel good. Romance novels are based on the idea of an innate emotional justice - the notion that good people in the world are rewarded and evil people are punished. In a romance the lovers who risk and struggle for each other and their relationship are rewarded with emotional justice and unconditional love. [7].

"Historical romance" is to be considered as a subcategory of the romance genre, presenting all the elements listed in the above reported definition, but within a historical context. While the historical component is clearly important, its function is not easy to define. In this regard, Helen Hughes notes how

The past setting may in such texts appear to add to the pleasure of the book because it can be presented as more colourful and exciting than the everyday life of the reader; but it may also be seen as an amniotic fluid in which the seeds of the present float [...] romantic writers use the past as an exotic setting to add to the escape value of their story: but it also functions as a mirror for the present. [8: p. 4]

In addition, it is not clear how "historical romances" differ from another form that also presents a fictionalised historical element, i.e. the "historical novel". Perhaps it would be better to talk of 'historical fiction' within which two bodies of narratives have developed: 'the historical romance' and 'the historical novel', although outlining in which way they differ is not easy, as Jeremy de Groot [9] has recently shown in a study discussing the features of the historical novel and its development into different subcategories. In particular, it is possible to identify a popular, uncomplicated, read-for leisure form, usually defined as 'historical romance', mainly produced and consumed by women and a 'nobler' form, usually seen as the offspring of a tradition dating back to Walter Scott and the development of the novel in the nineteenth century, which is usually referred to as 'the historical novel' and could be seen as being part of a patriarchal literary canon ${ }^{7}$.

The genre of 'historical romance' in its contemporary form took shape in the US in the early $1970 \mathrm{~s}^{8}$ with writers such as Kathleen Woodiwiss, whose 1972 novel The Flame and the Flower was a revolutionary book for those times, set at the turn of the nineteenth century and featuring an epic historical romance with a strong heroine and sex scenes.

Nowadays, historical romances are consumed addictively by millions of women, hence this is a florid economic sector

\footnotetext{
7 Katherine Cooper and Emma Short also see terms as 'historical romance' and 'historical fiction' as gendered labels [10]

8 Although the success of Woodiwiss's novel provided visibility to the genre, it must not be forgotten that novels defined as "historical romances" and written by women date back to the Eighteen Century (see Cooper and Short [10]) and that, even before Kathleen Woodiwiss, other writers helped to shape the form in the twentieth century. Kathleen Winsor pioneered the genre in 1944 with her successful book, Forever Amber, set in the seventeenth century (the book was transposed in a film production in 1947). In UK the novels of Georgette Heyer and Barbara Cartland were also particularly successful and invented the "Regency" subcategory, i.e. romantic novels set during the regency of George IV in Britain.
} 
of the publishing market not only for the USA, but also for other countries in which translation copyrights are sold. The reasons for this genre's success are numerous. On the one hand, these books are perceived to have a kind of pedagogical value: "Many readers say they not only enjoy the romance and excitement of historicals, but they feel they are learning something about the history of a different place and era" [11: p.113], an element also stressed by Janice Radway's research "readers believe it lends educational value to a habit which they fear would otherwise be dismissed as escapist self-indulgence". [12: p. 106].

Other intriguing elements of the reading experience felt as essential both from source and target readers are the locations. This is a particularly interesting issue from the point of view of translation problems and strategies, given that publishers actually decide what is worth translating also on the basis of its geographical setting. For example many novels particularly successful in the US market are set in the Far West or in remote rural areas of the USA, but these specific themes are not considered sufficiently appealing to European publishers, especially in the Italian market. Geography can become quite a problematic theme also from the point of view of the original writing plot, in a genre dominated by US writers, for whom Europe, especially Scotland, often seems to be regarded as a historical fantasy theme park [13: p.195].

Another crucial issue in terms of writing and translating publishing strategies related to mass market fiction is its tendency to gloss over potentially sensitive religious matters. The genre aims at appealing to as wide a demographic profile as possible, hence some portrayals of mediaeval Catholic beliefs and practices or religious conflicts (for instance between Christians and Muslims, or Catholics and Protestants) might risk alienating some readers. This is why the so called 'inspirational novels' where the heroines are deeply bound to a Protestant cultural context and background are so popular in the US but are not present in the European/Italian market [14].

Apart from the above mentioned Harlequin Mondadori, there are several other Italian mainstream publishers working in the sector and which have historical romance novels in their catalogue. Among these there are two, Sonzogno and Corbaccio ${ }^{9}$, who published the novel which is the subject of the present study, and whose catalogue is well known to Italian female readers for a number of successful titles within the field of historical romance.

\section{Analysis of a Case Study: the Novel Outlander}

As we have seen in the previous section, the distinction

9 Sonzogno is one of the oldest Italian publisher and since the mid nineteenth century, when it was founded, specialised in popular fiction, especially for women[15: p. 125]. Corbaccio is a Milan-based publishing house, founded in the $1920 \mathrm{~s}$, noted for a prestigious series of novels that published, amongst others, Luis-Ferdinand Celine's Journey to the End of the Night. between a 'historical novel' and a 'historical romance' is not so clear, in spite of the fact that the two labels are used to describe books marketed in a different way and addressed to different segments of the reading public. The question that we asked is how being given a specific label affects the translation of books, with the aim of getting insights into the translation practices of popular genres and how these practices help to identify particular generic features.

In the following case study we will examine this issue, focusing on the Italian translation of Outlander ${ }^{10}$ [16], the first book in a series of novels by American writer Diana Gabaldon which, since its publication in 1991, has become an international bestseller, translated into twenty four languages and the object of a number of intersemiotic translations ${ }^{11}$.

The book tells the story of Second World War nurse Claire Randall who, during a holiday in Scotland with her husband in 1945, enters a circle of standing stones and finds herself in eighteenth century Scotland, just before the Jacobite Rising. Told in the first person by Claire, the book's main focus is on the passionate love story that develops between her and Highland warrior James Fraser, but the narrative also offers the opportunity to describe life in the Scottish Highlands in the eighteenth century, including references to its history. So the book does combine different aspects, although the love story between the protagonists is by far the most important element.

The case of Outlander is particularly interesting in relation to our question because, since its initial publication, when it was generally identified as a romance ${ }^{12}$, the book has gone through a generic shift and tends now to be represented either as a historical novel or as a sort of "hybrid" narrative combining the conventions of different genres, romance, history and even science fiction/fantasy as, for example, was stated in an article published on the online magazine Salon "The smartest historical sci-fi adventure-romance story ever written" [17]. In this process of re-interpretation Diana Gabaldon herself has played an important role, using her authority as 'the author' to distance the book from the 'low' field of "romantic fiction' ${ }^{13}$ and highlighting its non-generic nature "...here we all are, still trying to figure out what the heck you call books that nobody can describe" [18]. Obviously, saying that Outlander cannot be described on the basis of the usual literary descriptors underlines its 'uniqueness' and re-positions it within the literary hierarchy, a strategy based on the argument that genre literature can be distinguished from 'high literature' thanks to the latter's 'unique' quality, its 'singularity', compared with the formulaic nature of popular genres [19:p. 40].

10 In the UK the novel was published with another title, Cross Stitch, which also showed some differences at the textual level.

11 A graphic novel with the title The Exile: An Outlander Graphic Novel was published in 2010 by Del Rey, illustrated by Hoang Nguye, while a serialized TV version of the first book was broadcast in 2014 in the US by TV network Starz.

12 In 1992 Outlander won the Romance Writers of America Rita Awards for best 1991 romance.

13 See also Jessica Matthews's abstract available on the webpage of the symposium "The Popular Romance Author", held at Princeton University on $25^{\text {th }}$ October, 2013: http://www.princeton.edu/prcw/abstracts/. 
Given the book's disputed identity, it is worth asking how the Italian translators/mediators dealt with this slippery generic identity and which interpretation of the book was offered within the Italian market, keeping in mind that, generally speaking, the labelling of texts into specific genres is favoured by publishers as a way to increase the books marketability. In short, while generic hybridity may be seen as an asset for the original text, this is probably not true in relation to its translations into other languages. As we will show, it did not happen in the Italian context where Outlander was translated twice, and interpreted once as a 'historical romance' and the second time as a 'historical novel'. The following analysis will highlight the implications of belonging to one or the other category at the para-textual and textual level.

\subsection{The Italian Translations of Outlander}

Outlander was first published in Italy in 1993 by Sonzogno, a shortened version of the original text with several cuts and summarized parts. At a paratextual level the book was clearly interpreted as a romance, especially through the title that was adapted in Italian and rendered as Ovunque nel tempo, [Anywhere in time] [20], followed by the subtitle "Una storia d'amore" [a love story]. The title was probably changed to make it more interesting and perhaps reflect the idea of "time travelling" which is part of the novel's plot. However, the subtitle narrows the range of possible interpretations, and, it is more likely that the title is perceived as referring to the idea of "eternity" and thus to the conventional trope of never ending love. This interpretation is further reinforced by the image on the cover which, in a subtler way, evokes an idea of a romantic and mysterious past by showing an ancient stone circle and, above it, the eyes of a woman. More visually explicit was the cover of a second edition of the Sonzogno translation distributed by the Club degli editori, a mail-order book sales club, with the conventionally "romantic" image of a woman in close-up and an embracing couple in period costumes in the background. No other book in the series appeared with this publisher. The author herself stated in a public Tweet in response to a reader's question ${ }^{14}$ that the translation rights were withdrawn because of cuts that significantly shortened the novel.

The book reappeared in the Italian market ten years later, with a new, more faithful, title La straniera $[\text { The foreigner }]^{15}$ [21], a new publisher Corbaccio, and a new unabridged translation. Looking again at the paratextual elements, it appears that this second edition took into account the shift of genre identity. Although from a visual point of view the cover maintains a certain "romantic" atmosphere, the image of a castle (The Scottish Castle Kilchum, according to the

14 In a Tweet dated 7th November 2013, which appeared in the Twitter page of Outlander World, Diana Gabaldon stated that she "Got the rights back", describing the first translation as a "BAD one".

15 In the following sections we will refer to the first translation Ovunque nel tempo as TT1(Target Text 1) and to the second translation La straniera as TT2 (Target Text 2) information given in the internal cover) can be taken as a conventional sign for "history" echoed by the blurb on the cover that states how the novel is "Una festa indimenticabile per tutti i lettori di storia, avventura e romanzi d'amore" [an unforgettable feast for all readers of history, adventure and romance], foregrounding the word "history". In addition, with its references to adventure, La straniera is potentially addressed to male readers as the image of the "castle" may also evoke a military content, a feature typical of historical fiction for men which, as de Groot explains, "tends to be more based in adventure and concerned in the main with warfare" [22: p.78]. The two editions therefore seem to reflect the "route" of the original text, its move from romance to historical novel. However, although during this shift the textual matter of the original text obviously remained the same, the two Italian versions show remarkable differences at a textual level, which indicate how translating 'history' and translating 'romance' are perceived as quite different activities. In particular, the several cuts, omissions and general manipulation of the first translation indicate that translating a book as a 'romance' authorizes radical interventions of a kind that are more typical in the most formulaic type of romantic fiction such as the Harlequin romances (see Kemppinen [23]). The second translation, on the contrary, does not present substantial cuts and remains, on the whole, fairly close to the source text. Apart from the differences concerning what may be defined as the general translation strategy, the two Italian versions show divergent choices also in relation to other textual categories.

One striking example regards the way in which the translators dealt with the problem of rendering cultural references, especially to Scottish and Gaelic culture. While English is the main narrative language, in the source text there are also many dialogues in Scots and, occasionally, Gaelic words and expressions. In the first translation (TT1) linguistic markers of foreignness have been erased, for example most references to Scottish culture are translated into Italian. On the contrary, in the second translation (TT2) many Scottish words are retained, even those that are unlikely to be understood by Italian readers, such as the Scottish words 'loch' [lake] and 'laird' [lord], or Scottish interjections such as Och and Ach. Interestingly, the second translation shows a tendency to retain also those English words that are currently understood and accepted in Italian language and culture, for example titles such as Mrs or Mr, or words that are accepted borrowings in Italian such as 'cottage' and 'bed and breakfast' which, instead, have been all rendered in Italian in the first translation.

In TT1 a different approach was adopted for the rendering of Gaelic words and expressions as a number of these were retained. One of these is the expression Mo duinne [my brown one], which is occasionally uttered by the male protagonist to the heroine as a term of endearment, and was probably retained in the Italian text because it was seen as a reinforcement of the love narrative. It is not clear, however, to what extent such choices are the result of a coherent strategy as, in other cases, the Gaelic words were translated. 
One instance of such inconsistency is the decision to translate what may be seen as the most important word of the text, the Gaelic term Sassenach [English person], a 'loaded' word [24] which may be used as a hostile term but which the hero turns into a word of affection for the heroine. In TT1 the word was rendered as "Sassone" [Saxon] which does not seem to fit with the context of Eighteen Century English-Scots conflict.

Table 1. The translation of references to English, Scottish and Gaelic cultures

\begin{tabular}{|c|c|c|}
\hline Source Text & Target Text 1 (TT1) & $\begin{array}{c}\text { Target Text 2 } \\
\text { (TT2) }\end{array}$ \\
\hline Mrs Bairds & La signora Bairds & Mrs Bairds \\
\hline Bed \& Breakfast & Pensione & Bed \& Breakfast \\
\hline The stone cottage & La casetta di pietra & Il cottage di pietra \\
\hline $\begin{array}{c}\text { Daughter of the } \\
\text { laird }\end{array}$ & $\begin{array}{c}\text { Figlia del proprietario } \\
\text { terriero }\end{array}$ & figlia del laird \\
\hline 'Och, aye' & Oh, oh, va bene! & 'Och, aye' \\
\hline Sassenach & Sassone & Sassenach \\
\hline
\end{tabular}

As already indicated, TT1 presents many cuts of descriptive parts, words that, although not essential to the general plot, are nonetheless important in providing information about the characters, their thoughts and feelings. Considering that, as Walter Nash [25] has pointed out, "In paperbacks of the Mills \& Boon type, dialogue is the customary mode of narration and the pictorial or descriptive element is a secondary feature", stripping the text of descriptive elements means getting the narrative closer to the type of highly formulaic language typical of category romances. It is, however, interesting to note that in TT1 omissions rarely affect the 'romantic' scenes, so when words are missing from love scenes it may be hypothesised that another rationale is at work. It can be noted, for example, the erasure of elements from a love scene for reasons that are not clear unless for the tendency in romantic fiction to cleanse the text of elements deemed as unsuitable to the representation of love. In a textual sequence where the two main characters get ready to make love for the first time, the word 'deflower' used by the female protagonist in relation to the male hero who is a virgin has been left out. Also erased was a reference about going to the toilet as shown in the example in Table 2.

Table 2. The translation of 'unsuitable' references

\begin{tabular}{|c|c|c|}
\hline Source text & Target Text 1 (TT1) & Target Text 2 (TT2) \\
\hline $\begin{array}{c}\text { Only letting go of } \\
\text { each other's hands } \\
\text { to pour wine or to } \\
\text { get up to visit the } \\
\text { privy stool behind } \\
\text { the curtain }\end{array}$ & $\begin{array}{c}\text { Lasciandoci le mani } \\
\text { solo per consumare } \\
\text { altro vino. } \\
\text { [Back Translation: } \\
\text { Letting go of each } \\
\text { other's hand only to } \\
\text { drink more wine] }\end{array}$ & $\begin{array}{c}\text { vino o per visitare la } \\
\text { seggetta situata dietro } \\
\text { la tenda } \\
\text { [Back Translation: } \\
\text { Letting go of each } \\
\text { other's hand only to } \\
\text { pour wine or to visit the } \\
\text { commode] }\end{array}$ \\
\hline
\end{tabular}

Apparently, interventions aimed at cleansing the text of 'unsuitable' references are typical in the translation of category romances. As a senior editor at Harlequin Mondadori explained in an interview, when a language is too crude and not literary enough the translator must "tenere alta la tensione erotica, far emergere $\mathrm{i}$ sentimenti, addolcire $\mathrm{i}$ passaggi più crudi o di dubbio gusto, eliminare quelli che rovinano l'atmosfera" [keep up the erotic tension, let people's feelings emerge, soften the parts that are coarse or in bad taste, eliminate those which ruin the atmosphere] [26]

Another element that we examined and which showed remarkable differences in the two translations was the rendering of historical references. In the examples shown in Table Three it is possible to see that in TT1 historical references were not the object of a particular translation strategy, while in TT2 the "historical" component has been highlighted, for example by using capital letters to refer to historical events as if to enhance the 'authority' of the reference as in example 1. In TT2 there are also footnotes (example 3) to explain some of the cultural and historical references, a feature that is in line with the tendency of historical novels to 'provide' documentation "historical novels are obsessed with paratexts: footnotes, additions, acknowledgments, bibliographies, author information, maps" [27: p.63].

Of particular interest is the second example where the historical reference to Prince Charles Stuart is translated simply as 'il principe Carlo', the same term used in Italian to refer to Prince Charles Windsor, the current heir to the British throne, thus creating an unwanted ambiguity.

Table 3. The translation of historical references

\begin{tabular}{|c|c|c|}
\hline Source Text & Target Text 1 (TT1) & Target Text 2 (TT2) \\
\hline $\begin{array}{c}\text { 1. The second - Jacobite } \\
\text { Rising }\end{array}$ & $\begin{array}{c}\text { La seconda rivolta } \\
\text { giacobita }\end{array}$ & La seconda Sommossa Giacobita \\
\hline $\begin{array}{c}\text { 2. It's the Rising... Prince } \\
\text { Charlie }\end{array}$ & $\begin{array}{c}\text { Si tratta della rivolta... il } \\
\text { principe Carlo }\end{array}$ & Prince Charlie. Ci sarà una Sommossa \\
\hline $\begin{array}{c}\text { 3. It was built well after the } \\
\text { Protector's time }\end{array}$ & (erased) & $\begin{array}{c}\text { E' stata costruita molto dopo l'epoca del Protettore (Footnote: Lord Protettore della } \\
\text { repubblica, titolo di Oliver Cromwell, 1599-1658) }\end{array}$ \\
\hline
\end{tabular}




\section{Conclusions}

This paper originated from the desire to explore the translation practices employed in the area of popular literature, a field that is still widely unexplored in translation studies. Our aim was to consider to what extent the use of particular generic labels affect the translation of texts. As we have shown, applying a specific label to a text is not just a matter of matching a particular narrative content with a defining word but might result in a series of interventions that strengthen the genre's more formulaic features. While the practice of neatly pigeon-holing narratives into specific genres seems to be favoured in relation to popular literature, in the case we examined this strategy was not a route to success. Judging by the words of praise for Valeria Galassi, the second translator of Outlander, expressed by readers in an Italian website dedicated to the novel ${ }^{16}$, it is clear that the second translation was thought of as much preferable to the first one. The question remains whether the translation of popular genres always results in the reinforcement of conventional features in terms of perceived generic identity, something that merits further analysis.

\section{REFERENCES}

[1] Fuchs, Barbara. Romance. Psychology Press, New York, 2004.

[2] Carmignani, Elide. "Tradurre l'amore in Harmony: a colloquio con le signore della Harlequin Mondadori”. WUZ, April 23rd 2012. Online, available at: http://www.wuz.it/articolo-libri/6906/Tradurre-lamore-collo quio-Harlequin-Mondadori.html. Last accessed: 28/07/2015

[3] Paizis, George. "Category Romances: Translation, Realism and Myth". The Translator, Vol.4, No 1, p. 1-24, 1998

[4] Weiss J. E., Fellow J., Dickson M. (eds.) Medieval Insular Romance: Translation and Innovation. Cambridge: Brewer, 2000.

[5] Shibamoto-Smith Janet S. (2005) "Translating True Love. Japanese Romance Fiction, Harlequin-Style". In José Santaemilia (ed.) Gender, Sex and Translation: The Manipulation of Identities. Manchester:St. Jerome Publishing

[6] Regis, Pamela. A Natural History of the Romance Novel. Philadelphia: University of Pennsylvania Press. 2003

[7] The Association of Romance Writers of America (RWA), website. Online, available at https://www.rwa.org/p/cm/ld/fid=578. Last accessed $28 / 07 / 2015$

[8] Hughes, Helen. The Historical Romance, Routledge, London, 1993.

[9] De Groot, Jerome. The Historical Novel. Routledge, London

16 The fans'comments are a response to an interview with the translator Valeria Galassi and appeared between 5 March and 29 June 2009. All are available at:

http://outlanderworld.blogspot.it/2009/03/intervista-valeria-galassi.html. Last accessed: 29/04/2015 and New York, 2009.

[10] Cooper Katherine and Emma Short. "Introduction: Histories and Heroines: the female figure in contemporary historical fiction". In K.Cooper and E.Short eds. The Female Figure in Contemporary Historical Fiction. Palgrave Macmillan, New York, 2012. 1-20

[11] Pianka Phyllis Taylor. How to Write Romances, Cincinnati: Writer's Digest Books, 1998.

[12] Radway, Janice. Reading the Romance. Women, Patriarchy and Popular Literature, Chapel Hill: University of North Carolina Press, 1991.

[13] Ramsdell, Kristin. Romance Fiction: A Guide to the Genre. (2nd edition) Santa Barbara: Libraries Unlimited, 2012.

[14] Carmignani, Elide. "Tradurre l'amore in Harmony: a colloquio con le signore della Harlequin Mondadori”. WUZ, April 23rd 2012. Online, available at: http://www.wuz.it/articolo-libri/6906/Tradurre-lamore-collo quio-Harlequin-Mondadori.html. Last accessed: 28/07/2015

[15] Marchetti, Ada Gigli. "Le nuove dimensioni dell'impresa editoriale”. In G. Turi (ed.) Storia dell'editoria nell'Italia contemporanea. Firenze: Giunti, 1997. 115-163

[16] Gabaldon Diana. Outlander, New York: Bantam Dell. 1992.

[17] McNett, Gavin. "My “Outlander" Thing”. Salon. Online, available at: http://www.salon.com/1999/08/12/outlander/, 1999. Last accessed: $30 / 07 / 15$

[18] The Outlander Series. Diana Gabaldon's website. Online, available at:

http://www.dianagabaldon.com/books/outlander-series/. Last accessed 30/07/2015.

[19] Gelder, Ken. Popular Fiction. The Logics and Practices of a Literary Field, London and New York: Routledge, 2004.

[20] Gabaldon, Diana. Ovunque nel tempo (trans. by De Angelis L.), Milano: Sonzogno, 1993.

[21] Gabaldon, Diana. La straniera (trans. by Galassi V.), Corbaccio, Milano 2003.

[22] De Groot, Jerome. The Historical Novel. Routledge, London and New York, 2009.

[23] Kemppinen, Anne. "Translation for Popular Literature with Special Reference to Harlequin Books and their Finnish Translation". In S.Tirkonnen-Condit and S.Condit (eds) Empirical Studies in Translation and Linguistics, Savonlinna: University of Joensuu, 1989. 25-36

[24] Scott M.. "Scots Word of the Season: Sassenach". The Bottle Imp. Issue 13. May 2013. Online, available at: http://www.arts.gla.ac.uk/ScotLit/ASLS/SWE/TBI/TBIIssue 13/Sassenach.html. Last accessed: 30/07/2015

[25] Nash, Walter. Language in Popular Fiction. London and New York: Routledge, 1990.

[26] Carmignani, Elide. "Tradurre l'amore in Harmony: a colloquio con le signore della Harlequin Mondadori". WUZ, April 23rd 2012. Online, available at: http://www.wuz.it/articolo-libri/6906/Tradurre-lamore-collo quio-Harlequin-Mondadori.html. Last accessed: 28/07/2015

[27] De Groot, Jerome. The Historical Novel. Routledge, London and New York, 2009 